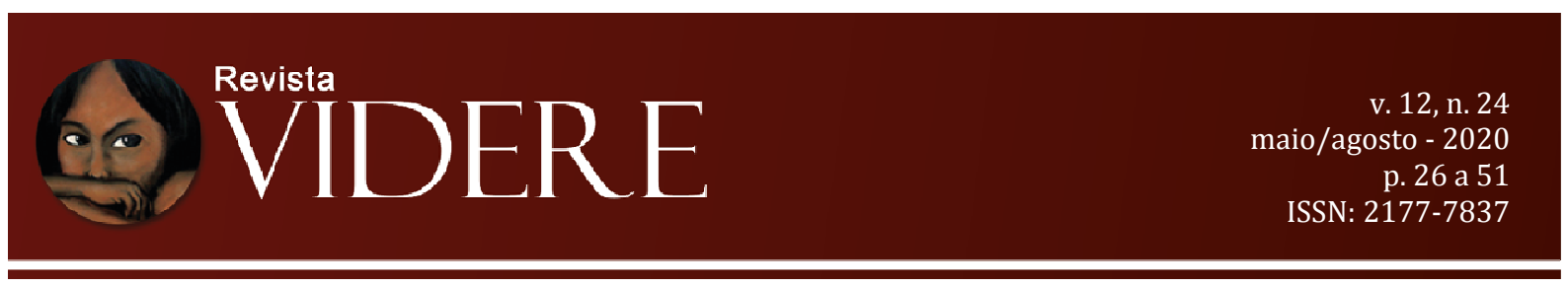

\title{
O PONTO CEGO LEGISLATIVO E A CRIMINALIZAÇÃO DA HOMOFOBIA
}

\author{
THE LEGISLATIVE BLINDSPOT AND THE HOMOPHOBIA'S \\ CRIMINALIZATION
}

\author{
Andressa Tanferri Sentone \\ Mestre em Ciência Jurídica pela Universidade do \\ Norte do Paraná (UENP), Brasil \\ Docente e coordenadora do curso de direito da \\ Unopar-Londrina, Brasil \\ E-mail: andressatanferri@gmail.com \\ OrcID: https://orcid.org/0000-0002-2991-272X
}

\author{
Gilberto Giacoia \\ Doutor em Direito pela Universidade de São Paulo \\ (USP), Brasil \\ Professor na graduação e na pós-graduação da \\ Universidade do Norte do Paraná (UENP), Brasil \\ E-mail: giacoia@gmail.com \\ OrcID: https://orcid.org/0000-0001-7082-4505
}

RESUMO: O presente artigo se dispõe a analisar o papel do Poder Judiciário, notadamente do Supremo Tribunal Federal, no que diz respeito à sua atuação proativa frente ao silêncio legislativo em matéria de criminalização da homofobia. Pretende-se, dessa forma, avaliar o atual sistema que envolve o direito das minorias LGBT e o distanciamento existente entre a legislação e a realidade protetiva dos seus direitos fundamentais. Insere-se nesta perspectiva a ausência de normatização própria acerca da tipificação das condutas discriminatórias, o que conduziu o Supremo Tribunal Federal, em julgamento ainda em curso, a adotar uma postura ativista e tender a decidir de forma favorável à tipificação da homofobia após constatar a omissão do Poder Legislativo. Desta forma, este estudo se prestará a realizar uma abordagem crítica sobre essa atuação do STF, a fim de examinar os fundamentos, os limites da sua atuação e eventual entraves à sua efetivação.

PALAVRAS-CHAVE: Ativismo judicial. Silêncio legislativo. Direito das minorias. Criminalização da homofobia.

\footnotetext{
ABSTRACT: This article sets out to analyze the role of the Judiciary, especially the Federal Supreme Court, regarding its proactive action against the legislative silence regarding the criminalization of homophobia. The aim is to evaluate the current system involving the right of LGBT minorities and the distance between legislation and the protective reality of their fundamental rights. In this perspective, the absence of specific laws on the definition of discriminatory conduct, which led the Federal Supreme Court, in a judgment still in progress, to adopt an activist stance and tend to decide favorably to the typification of homophobia after verifying the omission of the Legislative Branch. In this way, this study will provide a critical approach to this STF performance, in order to examine the fundamentals, the limits of its action and eventual obstacles to its implementation.
} 
KEYWORDS: Judicial activism. Legislative silence. Minority rights. Homophobia's criminalization.

\section{Introdução}

O avanço na proteção dos direitos fundamentais expandiu o caráter fragmentário do século XVIII, em uma sistemática universalista, no qual apenas as liberdades individuais eram permeadas de proteção estatal, para reconhecer o ser humano como sujeito de direitos nas suas mais variadas acepções. Porém, a velocidade das circunstâncias sociais acaba distanciando as leis da realidade dos conflitos.

Ao Legislativo, poder eleito, cuja função típica consiste na criação de leis para regular o Estado e à própria sociedade, caberia, pois, disciplinar as demandas sociais com leis necessárias a esta dinâmica. Todavia, quando esse papel não é exercido, a sociedade fica diante de uma barreira ao desenvolvimento e progresso de leis adequadas ao tempo presente, chamada de ponto cego legislativo.

Diante da inércia do Legislativo, que se abstém de solucionar conflitos dramáticos envolvendo direitos fundamentais, em regra por razões políticas, resta ao Judiciário abraçar uma postura mais proativa na interpretação das normas existentes, a fim de adequá-las às necessidades jurídicas, políticas, culturais e sociais do presente e de compatibilizá-las com a Constituição.

A homofobia ainda é considerada um desses temas conflitantes, um problema de política criminal, que envolve embates morais, jurídicos e políticos, carecendo de regulamentação e proteção específica. Nesse diapasão, constantemente o assunto vem sendo objeto de demandas judiciais que chegam até o Supremo Tribunal Federal visando a colmatação e o preenchimento das lacunas legislativas.

A ideia deste estudo é apresentar de que forma a interpretação criativa da Corte Constitucional vem sendo utilizada para modificar, complementar e até mesmo corrigir a aplicação da lei penal em situações específicas alusiva aos crimes de discriminação motivados pela orientação sexual, fazendo o uso de princípios e da ponderação de direitos para concretizar os preceitos constitucionais.

Para tanto, o presente trabalho apresentará no primeiro momento a evolução dos direitos fundamentais das minorias, tanto no âmbito nacional, como internacional, com o intuito de demonstrar a proteção legislativa insipiente na seara dos direitos LGBT, bem como 
o hiato existente entre a sua efetividade e o atual momento de violência e segregação experimentado por essa população.

Em seguida, discorrerá sobre a atuação da Corte Constitucional brasileira frente ao silêncio legislativo, a postura adotada na tomada de decisões, a mudança de paradigma na Corte, o desprendimento da interpretação literal das normas e a adoção de uma posição concretista e contramajoritária na defesa dos direitos fundamentais.

Por fim, será analisada a inclinação recente do Supremo Tribunal Federal em não só declarar a omissão constitucional, mas criminalizar a homofobia a partir de uma justificativa de interpretação da norma, agindo como protagonista institucional no processo de transformação social, abordando os principais argumentos e as críticas sobre as balizas dessa atuação criativa.

O objetivo principal do presente estudo, consiste, pois, em fazer uma abordagem da atuação da Corte Constitucional frente à inércia legislativa para tratar do tema relativo à punição de condutas que atentem contra os direitos sexuais do grupo LGBT, analisando sua recente atuação na ADO 26 e no MI 4733, ainda em curso.

Busca-se, pois, ponderar se a atuação do Judiciário para suprir as lacunas legislativas existentes é legítima ou se ocorre a violação à separação dos poderes a partir da decisão que interpreta extensivamente o conceito de racismo para a inclusão de condutas que violam os direitos LGBT no âmbito de proteção do tipo penal. Este embate envolve, de um lado, a perspectiva do ativismo, pautada em um constitucionalismo moderno e no póspositivismo, que encoraja a produção de jurisprudências progressistas e interpretam o direito de forma mais ampliada, e, de outro, a própria teoria da tripartição dos poderes, elaborada por Montesquieu, que prevê uma atuação harmônica, porém, independente entre os poderes Legislativo, Executivo e Judiciário.

Ressalta-se que a ideia da pesquisa não é esgotar a discussão sobre o tema, mas apontar que, em que pese a atuação ativista do Judiciário auxilie na efetivação dos direitos fundamentais assegurados pela Constituição, a sua utilização em excesso pode vir a extrapolar os limites jurisdicionais e gerar, inclusive, uma aparente hierarquia entre os poderes, que iria de encontro às bases democráticas da legislação brasileira.

O método escolhido para desenvolver a pesquisa, de caráter eminentemente teórico, foi o dedutivo, com revisão bibliográfica e documental, partindo de premissas gerais e verdadeiras relacionadas ao ativismo judicial e objetivando chegar a uma conclusão específica a respeito da mencionada postura proativa do Supremo Tribunal Federal na defesa dos direitos das minorias. 


\section{Os direitos fundamentais das minorias}

O Brasil, como Estado Democrático de Direito, possui um rol extenso de direitos fundamentais positivados na Constituição. A partir da promulgação da Constituição Federal de 1988 esse rol foi ampliado, no sentido de resguardar direitos individuais e coletivos de todos as pessoas, assegurando o tratamento igualitário e digno, sem distinção de qualquer natureza.

Além de assegurar ao povo o exercício da igualdade e liberdade, a Constituição, conferiu destaque à dignidade como princípio fundamental, garantindo a todos o direito de escolha para serem aquilo que lhes melhor convier, desde que não haja proibição em lei, dentro de uma sociedade pluralista e livre de preconceitos, o que inclui a livre orientação sexual.

A grande miscigenação do Brasil, resultado de uma mistura de diversas etnias, culturas, ideologias e religiões, é fator que confere ao país uma identidade cultural extremamente variada. Diante disso, a normativização jurídica se faz necessária para proteger as multifacetadas expressões culturais, com intuito de tornar inaceitável toda e qualquer forma ou ato discriminatório busque inferiorizar ou excluir determinado grupo e que atente contra os princípios positivados:

Tanto no âmbito sociológico quanto no âmbito jurídico, as diferenças étnicas, raciais, culturais e de origem - sempre existirão, já que os homens são naturalmente desiguais. O que se deve garantir - e, nesse sentido, admite-se uma atuação positiva do Estado - é que tais dessemelhanças não deem azo à marginalização social de certos grupos. O ideal de justiça - ou de igualdade justa - no qual o direito deve centrar-se está vinculado à minimização das desigualdades fundadas na diversidade racial. (MIRANDA, 2013, p. 258).

O conceito de minoria pode ser definido pelo critério objetivo da exclusão social e da falta de participação nas decisões políticas (LOPES, 2008, p. 20) ou ainda "como sendo determinados grupos humanos ou sociais que estejam em inferioridade numérica ou em situação de subordinação socioeconômica, política ou cultural, em relação a outro grupo, que é considerado majoritário ou dominante em uma dada sociedade" (PEREIRA e SALVIANO, 2015, p. 212). O termo 'vulneráveis' também é utilizado como sinônimo de 'minorias' e qualifica os grupos que necessitam de uma proteção especial para garantia dos seus direitos e igualdade de oportunidades que, em regra, lhes são obstaculizados. 
O tradicional conceito considera especialmente as características linguísticas, religiosas ou étnicas de um grupo para sua definição como minoritário. Porém, este rol não pode ser taxativo e deve ser ampliado considerando-se outras características passíveis de serem aplicadas na definição, analisando-se a cultura e a realidade de cada sociedade (LOPES, 2008, p. 20-21). Nesse sentido, é que os grupos LGBTs enquadram-se no conceito de minoria ou vulnerabilidade, pois, além de serem minoria quantitativa, são frequentemente submetidos à diversas formas de preconceito e discriminação.

Assim, na prática o que se verifica é o fato de que é mais comum se estabelecer direitos gerais, voltados à todos os indivíduos, do que prever-se normas específicas que visam contemplar determinados grupos de pessoas que necessitam, por alguma razão, de uma proteção especial. Como decorrência, acaba-se por não proteger adequadamente certos agrupamentos de pessoas e a não efetivar-se, a contento, os direitos daqueles tidos como diferentes e mais fracos, isto é, das minorias. (PEREIRA e SALVIANO, 2015, p. 211).

Dentro desse contexto, emerge, com nitidez, a relevância de uma proteção jurídica contra a discriminação em razão da orientação sexual, focada não apenas nas relações indivíduo-Estado, mas também nas relações entre particulares, tradicionalmente consideradas como impenetráveis pelos poderes públicos, em virtude do escudo protetivo formado pelos princípios da liberdade e da autonomia da vontade. (MIRANDA, p. 258)

No âmbito internacional, a ONU, somente em 1994, declarou que leis que infrinjam os direitos LGBT violam as leis de Direitos Humanos (GORISCH, 2014, p. 41), contudo, apenas em 2011 foi editada a primeira Resolução para regulamentar o tema, denominada de "Direitos Humanos, orientação sexual e identidade de gênero", apresentada pelo Brasil e África do Sul.

Apesar do progresso reconhecível da proteção jurídica aos homossexuais na esfera internacional de direitos humanos, verifica-se ainda que a concretização de tais direitos é um desafio hercúleo. Na contramão desses preceitos, cumpre citar, como exemplo, a Uganda, que recentemente discute um projeto de lei que propõe a pena de morte aos homossexuais e penas de até sete anos para amigos e familiares que deixarem de reportar sobre a existência de homossexuais às autoridades. Destaca-se que a pena de morte para homossexuais ativos que tenham o vírus HIV já é prevista na lei vigente do país. 
Nos dados de 2019 divulgados pelo ILGA $^{20}$ (International Lesbian, Gay, Bisexual, Trans and Intersex Association) constata-se que 70 países ainda consideram crime a relação entre pessoas do mesmo sexo, com penas que variam de multas e prisão à pena de morte, esta última ainda passível de aplicação em 11 países, a maioria deles situada no Oriente Médio. Ainda segundo estes dados, apenas 9 países asseguram proteção constitucional ao tema, sendo que a maioria garante a legalidade das relações homossexuais apenas em suas legislações ordinárias ou entendimentos jurisprudenciais.

Nessa classificação, o Brasil entra na categoria de ampla proteção, pois, além dos princípios constitucionais assegurarem a igualdade, o respeito e a tolerância a todos os cidadãos, o país reconheceu normativamente, por meio da Resolução CNJ 175/2013, o casamento entre pessoas do mesmo sexo, considerando que não há diferença entre a união de casais heterossexuais e casais homossexuais, garantindo, por conseguinte, a liberdade de escolha no reconhecimento formal de sua relação afetiva.

Anteriormente, o STF já havia reconhecido o direito de união de pessoas do mesmo sexo e a inconstitucionalidade de distinção de tratamento legal a estas uniões, no julgamento da ADPF 132/RJ e da ADI 4277/DF, que foi proferido com eficácia erga omnes e efeito vinculante, com fundamento na proibição de discriminação das pessoas em razão do sexo, na proibição do preconceito como capítulo do constitucionalismo fraternal, no respeito ao pluralismo como valor sócio-político-cultural, na liberdade para dispor da própria sexualidade e no direito à intimidade e à vida privada:

No mérito, julgo procedentes as duas ações em causa. Pelo que dou ao art. 1.723 do Código Civil interpretação conforme à Constituição para dele excluir qualquer significado que impeça o reconhecimento da união contínua, pública e duradoura entre pessoas do mesmo sexo como "entidade familiar", entendida esta como sinônimo perfeito de "família". Reconhecimento que é de ser feito segundo as mesmas regras e com as mesmas consequências da união estável heteroafetiva (BRASIL, online, 2011).

Outrossim, merece destaque a Portaria $\mathrm{n}^{\mathrm{o}} 766^{21}$, de 3 de Julho de 2013, da Secretaria de Direitos Humanos da Presidência da República, que instituiu o Sistema Nacional de Promoção de Direitos e Enfrentamento à Violência Contra Lésbicas, Gays,

\footnotetext{
${ }^{20}$ Edição do relatório ILGA's State-Sponsored Homophobia de 20 de março de 2019. Disponível em: <https://ilga.org/maps-sexual-orientation-laws>

${ }^{21}$ BRASIL. Presidência da República. Portaria no 766, de 03 de julho de 2013. Institui o sistema nacional de promoção de direitos e enfrentamento à violência contra lésbicas, gays, bissexuais, travestis e transexuais - LGBT e dá outras providências. Disponível em: <www. justica.info/diarios/85748132/dou-secao-1-10-022015-pg-1>. Acesso em: 20 maio 2017.
} 
Bissexuais, Travestis e Transexuais, cuja finalidade precípua consiste em organizar e promover políticas de promoção da cidadania e direitos de LGBT.

A despeito desse grande passo no reconhecimento dos direitos LGBT, a temática ainda permanece no limbo jurídico à espera de legislações que garantam uma igualdade material e que combatam à discriminação homofóbica e transfóbica, conforme as resoluções da ONU e da OEA, que reconhecem os direitos LGBTs como Direitos Humanos.

Como se não bastasse a dificuldade legislativa, a sociedade, adotando uma postura conservadora, tem colocado óbices à legitimidade dos direitos sexuais da população LGBT, estigmatizando pautas de reivindicações por entender que contrariam as normas heterocêntricas que dão sustentáculo ao conceito de família, sob a estrutura fundante da moral e dos seus pressupostos éticos e legais. Numa abordagem objetiva, adentra-se às questões que consolidam um cenário de retrocesso, ou de impedimento da progressão dos direitos e garantias da população LGBT (FELDENS, MOTA e MELO, 2017, p. 79).

O Poder Judiciário, adotando uma postura mais ativa, tem trazido à baila contribuições salutares para o aprofundamento das discussões a respeito da proteção dos direitos sexuais da comunidade LGBT, sobretudo quando o enfrentamento de tais questões pelo Poder Legislativo não se coaduna com os anseios políticos de seus representantes, cabendo à Corte Constitucional, em última instância, atuar frente ao silêncio do legislador.

\section{A atuação da Corte Constitucional Brasileira frente ao silêncio legislativo}

Diante da acelerada evolução social, política e cultural, o Poder Judiciário tem ocupado um papel de destaque no cenário sociopolítico brasileiro nas últimas décadas, especialmente após o advento da Constituição de 1988, quando passou a atuar proativamente frente a temas relevantes e controversos, inclusive políticos, que são constantemente levados à apreciação do Tribunal, ora porque a legislação existente para tratar do assunto é insuficiente, ora porque distante da realidade em face da época de sua criação ou em alguns casos totalmente omissa.

Assim, a fim de que as leis possam acompanhar o desenvolvimento e a velocidade dos conflitos sociais, o Supremo Tribunal Federal tem atuado, por meio de técnicas interpretativas e decisórias, na defesa dos direitos constitucionalmente assegurados, sobre questões que usualmente deveriam ser solucionadas por outros poderes, em especial o legislativo, a quem incumbiria de fato a elaboração e modificação das leis. 
Essa prática vem sendo aplicada à temática do presente trabalho no que concerne a decisões relativas aos direitos LGBT, notadamente quanto à criminalização da homofobia. Quando se aborda a questão da omissão legislativa leva-se em consideração a ausência de efetiva atuação do Legislativo na discussão sobre a matéria, assim como de tomada de conclusões a respeito do assunto. Nota-se que a discriminação motivada por questões relativas à orientação sexual há muito tempo é considerada um problema de política criminal e que a discussão a respeito da necessidade de sua tipificação não é recente.

O projeto de lei de autoria da Deputada Iara Bernardi $n^{\circ}$ 5003/01, que propunha a alteração da Lei $n^{\circ}$ 7716/89 incluindo no rol de crimes resultantes de preconceito a elementar relativa ao gênero, bem como do parágrafo $3^{\circ}$ do art. 140 do Código Penal, para que a injúria consistente na utilização de elementos relacionados à orientação sexual também fosse considerada qualificada, foi aprovado na Câmara dos Deputados em 2006 e, após, arquivado no Senado Federal (PL n ${ }^{\circ}$ 122/2006).

Posteriormente, foi requerido o seu desarquivamento (Requerimento $n^{\circ} 46 / 2011$ ) tendo sido retomada a tramitação do projeto. Porém, com vistas as protelar o andamento do feito, parlamentares contrários à criminalização da homofobia anexaram o projeto em questão ao PL 236/2012 que trata da instituição do Novo Código Penal brasileiro, gerando atraso na apreciação do projeto original, que tramita há mais de dezoito anos sem apreciação sequer da Comissão de Constituição, Justiça e Cidadania do Senado Federal, encontrando-se, até o presente momento, "sem prazo para ser votado" (BRASIL, online, 2019).

A conduta adotada pelo Legislativo demonstra a omissão na sua atuação, eis que os projetos que envolvem a temática não são sequer pautados para votação e, quando levados à discussão, não se debatem os aspectos jurídicos do tema, importando mais o peso de argumentos religiosos e morais defendida por cada partido em particular, que não podem se confundir com a tecnicidade jurídica exigida pelo assunto.

Uma nova proposta legislativa (OLS $n^{\circ}$ 515/2017) que visa incluir à discriminação de gênero no rol taxativo do racismo e na qualificadora do crime de injúria, elaborada pela Comissão de Direitos Humanos e Legislação Participativa foi apresentada no Senado e está em análise perante a Comissão de Constituição e Justiça atualmente, mas corre o risco de ter o mesmo destino da anterior, caso não haja maior engajamento político, pressão popular ou até mesmo uma determinação judicial.

A tentativa de modificação da lei penal por meio de processo legislativo não tem obtido êxito. A falta de agenda política para tratar com seriedade o assunto está intimamente relacionada à rejeição de grande parte da população ao tema, o que faz com que a matéria 
enfrente o que os cientistas políticos chamam de "ponto cego legislativo" (legislative blindspot), ou seja, temas que não são alcançados pelo debate parlamentar. Nesse sentido, discorreu o Ministro Marco Aurélio em seu voto na ADPF 347:

Legisladores e governantes temem os custos políticos decorrentes da escolha por esse caminho, acarretando a incapacidade da democracia parlamentar e dos governos popularmente eleitos de resolver graves problemas de direitos fundamentais. A história possui vários exemplos de agentes políticos haverem acionado cortes constitucionais, visando encontrar soluções a casos moralmente controvertidos e impopulares e, assim, evitar choques com a opinião púbica. Os poderes majoritários apostam no perfil contramajoritário das cortes constitucionais ou supremas: condenadas judicialmente a atuar, autoridades públicas se escudam no Estado de Direito e no consectário dever de observar ordens judiciais para implementar aquilo que teriam feito voluntariamente se não temessem custos políticos (STF, online, 2015).

No entanto, ainda se verifica a dificuldade do Legislativo em analisar objetivamente os aspectos jurídicos acerca da ponderação de direitos fundamentais, sem incutir nos debates aspectos pessoais e convicções particulares ou mesmo da própria ideologia do partido ao qual pertencem os seus membros, principalmente em assuntos que envolvem um grau elevado de complexidade e ampla repercussão social.

Assim, diante da demora ou ausência de atitude legislativa do Poder legitimado, o Judiciário, diante da frequente violação de direitos fundamentais, acaba por adotar postura ativa ao decidir sobre questões de cunho político, de implementação de políticas públicas ou escolhas morais em temas controversos na sociedade, ainda que em sede criminal, interpretando-as conforme a norma constitucional e os princípios democráticos. Essa atuação criativa do Supremo é denominada de ativismo judicial. Segundo conceito de Miarelli e Lima:

Por "ativismo judicial" entende-se o papel criativo dos tribunais ao fazerem uma contribuição nova para o direito, decidindo sobre a singularidade ao caso concreto, formando o precedente jurisprudencial, antecipando-se, muitas vezes, à formulação da própria lei. Diante de necessidades que forjam uma determinada interpretação, do texto de lei, é o momento em que o esforço do interprete faz-se sentir. Tem-se como ativismo judicial, portanto, a energia emanada dos tribunais no processo da criação do direito (MIARELLI e LIMA, 2012, p. 34).

O ativismo judicial é, portanto, a atitude proativa do aplicador da norma, que, ao interpretar a Constituição, expande o seu sentido e alcance. Normalmente ele se instala em situações de retração do Poder Legislativo, de um certo descolamento entre a classe política e a sociedade civil, impedindo que as demandas sociais sejam atendidas de maneira efetiva (BARROSO, 2010, p. 389). 
O espaço característico do ativismo judicial é o das importantes questões constitucionais, aquelas que interferem marcadamente nos processos político-democráticos, que se ocupam de tormentosos conflitos de valores morais e políticos, principalmente envolvendo direitos fundamentais e limites de autoridade do governo, que mobilizam os poderes políticos e a sociedade em torno da solução a ser dada pela corte, como discriminação racial e de gênero; ações afirmativas; aborto; direito à morte digna; direito das minorias; direito dos homossexuais; pena de morte; políticas públicas e justiça distributiva; etc. (CAMPOS, 2014, p. 140).

O Supremo Tribunal Federal há certo tempo vem adotando uma nova postura em suas decisões, que marca uma mudança de paradigma na corte, passando a consolidar uma posição concretista e contramajoritária, que rejeita o populismo judiciário e serve como instrumento de combate ao silêncio legislativo:

Em virtude da inércia do legislador em colmatar as lacunas constitucionais, após 20 anos do texto constitucional, o Supremo Tribunal Federal alterou seu posicionamento e adotando claro ativismo judicial passou a adotar a posição concretista, tanto geral, quanto individual (MORAES, 2012, p. 186).

As mudanças sociais ocorrem de forma muito célere, assim como o surgimento de novas questões levadas à apreciação do Judiciário. Ocorre que a legislação não caminha no mesmo ritmo, o próprio Código Penal de 1940 foi publicado segundo a cultura, costumes e hábitos dominantes na década de 30. Passaram-se oitenta anos, e, nesse lapso, não foram apenas os valores da sociedade que se modificaram, mas principalmente os avanços científicos e tecnológicos, que produziram verdadeira revolução na ciência médica (BITENCOURT, 2017, p. 184).

No ativismo judicial os juízes não se sentem presos ao sentido literal do texto normativo, ao contrário, buscam manter a constituição compatível com as circunstâncias sociais, sempre em transformação, fazendo o uso da interpretação criativa para tanto. Em outras palavras, os juízes ativistas decidem sobre valores morais da sociedade ao encontro da concretização de direitos fundamentais da sociedade e das normas constitucionais (CAMPOS, p. 159). "Juízes ativistas podem ser arquitetos sociais e a interpretação criativa das constituições é o instrumento legítimo dessa atuação" (CAMPOS, 2014, p. 154).

Nesse cariz, o Ministro Gilmar Mendes já consignou em mais de uma oportunidade a sua filiação ao emprego de técnicas menos ortodoxas de decisão no controle de constitucionalidade, sobretudo das decisões modificativas dos sentidos originais do texto as chamadas sentenças aditivas e modificativas -, por se tratar de uma necessidade prática 
comum a qualquer jurisdição constitucional, sobretudo pela imprecisão dos conceitos originais ou da inevitabilidade de adaptação do sentido à realidade social. Nessa linha, é o escólio do Ministro que elucida o tema:

É possível antever que o Supremo Tribunal Federal acabe por se livrar do vetusto dogma do legislador negativo e se alie à mais progressiva linha jurisprudencial das decisões interpretativas com eficácia aditiva, já adotada pelas principais cortes constitucionais europeias. A assunção de uma atividade criativa pelo Tribunal poderá ser determinante para a solução de antigos problemas relacionados à inconstitucionalidade, que muitas vezes causam entraves para a efetivação de direitos e garantias fundamentais assegurados pelo texto constitucional (BRASIL, online, 2006).

Apesar das críticas relacionadas à falta de legitimidade democrática direta do Judiciário para atuar de forma expansiva, indo além da interpretação restritiva da lei em suas decisões, deve-se destacar que, em face da vitaliciedade do cargo, os ministros não serão punidos ou destituídos ao tomarem decisões necessárias sobre assuntos polêmicos, que desagradam parte da população, buscando proteger o direito das minorias. Sobre o papel contramajoritário da jurisdição constitucional e a sua posição de guardião dos direitos fundamentais e do Estado Democrático de Direito aduzem Brega Filho e Alves:

Pensamos, contudo, que isso, considerando que o Supremo Tribunal Federal muitas vezes deve exercer um papel contramajoritário, ao invés de ser um defeito, seja uma virtude. Sabendo que não podem ser controlados pelo povo através do voto, os Ministros podem ter mais isenção em suas decisões (BREGA FILHO e ALVES, 2015, p. 130).

Outra crítica acerca do ativismo paira sobre a exasperação do Judiciário de suas funções típicas e atípicas, atuando supostamente como um legislador indireto, ferindo, desta feita, o princípio da separação dos poderes.

Sobre a separação dos poderes e a ilegitimidade do Judiciário para legislar, Machado entende que não cabe a este Poder modificar opções políticas realizadas por poderes escolhidos democraticamente para tanto, pois os juízes não são portadores de verdades superiores e devem se limitar a preservar o sistema político contra decisões frutos de vontades distorcidas e que colocam em risco a continuidade da democracia (MACHADO, 2011, p. 134137). "Daí que a intromissão em escolhas, mesmo que equivocadas, mas constitucionais, não é passível e controle pelo Judiciário. É o custo da democracia. Resta-nos aguardar o próximo mandato e trocar de política (políticos)" (MACHADO, 2011, p. 138).

Para Daniel Sarmento, outro efeito adverso do ativismo judiciário seria a ingerência desarrazoada na própria democracia, uma vez que tal mecanismo possibilita, se 
usado de forma equivocada, o monopólio da última palavra pelo Supremo Tribunal Federal, desestruturando, como consectário lógico, a própria separação dos poderes e os mecanismo de freios e contrapesos, inerentes ao Regime Democrático de Direito. Eis a lição:

E a outra face da moeda é o lado do decisionismo e do "oba-oba". Acontece que muitos juízes, deslumbrados diante dos princípios e da possibilidade de através deles, buscarem a justiça - ou que entendem por justiça -, passaram a negligenciar no seu dever de fundamentar racionalmente os seus julgamentos. Esta "euforia" com os princípios abriu um espaço muito maior para o decisionismo judicial. Um decisionismo travestido sob as vestes do politicamente correto, orgulhoso com seus jargões grandiloquentes e com a sua retórica inflamada, mas sempre um decisionismo. Os princípios constitucionais, neste quadro, converteram-se em verdadeiras "varinhas de condão": com eles, o julgador de plantão consegue fazer quase tudo o que quiser. Esta prática é profundamente danosa a valores extremamente caros ao Estado Democrático de Direito. Ela é prejudicial à democracia, porque permite que juízes não eleitos imponham a suas preferências e valores aos jurisdicionados, muitas vezes passando por cima de deliberações do legislador. Ela compromete a separação dos poderes, porque dilui a fronteira entre as funções judiciais e legislativas. E ela atenta contra a segurança jurídica, porque torna o direito muito menos previsível, fazendo-o dependente das idiossincrasias do juiz de plantão, e prejudicando com isso a capacidade do cidadão de planejar a própria vida com antecedência, de acordo com o conhecimento prévio do ordenamento jurídico (SARMENTO, 2007, p. 144).

Ronald Dworkin vai além, para o jurista a técnica do ativismo judicial prejudica a própria noção de subjetivismo jurídico, implicando na intervenção dos demais poderes e destroçando os longos períodos de batalha democrática e respeito a constituição. Assim preceitua:

O ativismo é uma forma virulenta de pragmatismo jurídico. Um juiz ativista ignoraria o texto da Constituição, a história de sua promulgação, as decisões anteriores da Suprema Corte que buscaram interpretá-la e as duradouras tradições de nossa cultura política. $\mathrm{O}$ ativista ignoraria tudo isso para impor a outros poderes do Estado seu próprio ponto de vista sobre o que a justiça exige. $\mathrm{O}$ direito como integridade condena o ativismo e qualquer prática de jurisdição constitucional que lhe esteja próxima (DWORKIN, 1999, p. 451452).

Não obstante, a vantagem prática do ativismo judicial e suas decisões estruturais é a possibilidade de aplicação ponderada da norma, buscando relacionar os meios disponíveis, os fins estabelecidos pelo ordenamento jurídico e os efeitos concretos da norma jurídica discutida para a proteção da pessoa, ora de forma imediata, ora por meio de comandos escalonados de implementação. O resultado desse processo interpretativo judicial pode ser replicado e constituir-se, após reiteradas decisões, em jurisprudência, que servirá como 
normativa válida no sistema jurídico vigente, sem que necessariamente se produza uma lei específica ou expressa. Nesse sentido, nota-se o caráter preventivo de tal mecanismo, que serve, outrossim, para prevenir ou mesmo evitar a perpetuação de uma determinada violação de direitos, por ausência ou morosidade na reforma das leis.

Sobreleva destacar que, apesar da importância do ativismo judicial na proteção dos direitos fundamentais, ele não pode ser exercido de forma indiscriminada, devendo sempre ser aplicado com base na racionalidade jurídica vigente, com uma análise minuciosa dos impactos das decisões para a sociedade e com auxílio técnico quando relacionadas a questões específicas que fogem ao conhecimento dos magistrados. Qualquer decisão ativista que se afastar dos objetivos de garantia dos direitos fundamentais e da supremacia da Constituição poderá ser considerada nociva, sobretudo se fazer preponderar um padrão de racionalidade eminentemente político (TEIXEIRA, 2012, p. 46).

Ademais, os princípios constitucionais, positivados expressa e implicitamente, estão amalgamados com a base externa que podem justificar ou não as leis criminalizadora, limitando ou não o seu conteúdo. Suas irradiações importam numa demarcação racional das possibilidades do legislador e do juiz, circunscrevendo a discricionariedade e a interpretação legislativa e judiciária, funcionando como uma espécie de parâmetro argumentativo para o controle da atividade destes atores. Daí deriva, portanto, que o próprio texto constitucional limita objetivamente a interpretação do Judiciário, sendo frontal a ofensa à Constituição quando se chega ao ponto de reescrever o seu conteúdo (RAMOS, 2010, p. 131).

Em suma, para garantir a legitimidade de suas decisões, o Judiciário ao fazer uso do ativismo judicial, deve motivar as suas decisões com argumentos racionais e persuasivos, dotados de razões públicas, a partir de um exame criterioso dos casos concretos, respeitando os limites dos princípios e regras constitucionais e utilizando-se da proporcionalidade e da ponderação sempre que houver colisão entre princípios.

\section{Uma análise crítica do papel do judiciário brasileiro na criminalização da homofobia}

O caminho na busca de reconhecimento e afirmação dos direitos fundamentais confere ao Supremo Tribunal Federal o papel de zelar pela concretização do extenso rol de direitos assegurados pelo Estado Democrático. Como guardião da Constituição, destaca-se o relevante papel do judiciário na proteção das minorias contra os excessos, violações e omissões dos seus direitos. 
O termo intolerância, em linhas gerais, refere-se à aversão ou não aceitação de ideias, opiniões, crenças ou indivíduos considerados diferentes do agente. Geralmente fundada num preconceito em relação àquilo ou àquele que é diverso, pode levar a comportamentos discriminatórios e, até mesmo, aos chamados crimes de ódio (MIRANDA, p. 265).

O preconceito, portanto, é fundamento para a manifestação da intolerância, que se materializa por meio de ações discriminatórias, em regra contra grupos socialmente inferiorizados, como os LGBT:

Por preconceito, designam-se as percepções mentais negativas em face de indivíduos e de grupos socialmente inferiorizados, bem como as representações sociais conectadas a tais percepções. Já o termo discriminação designa a materialização, no plano concreto das relações sociais, de atitudes arbitrárias, comissivas ou omissivas, relacionadas ao preconceito, que produzem violação de direitos dos indivíduos e dos grupos. O primeiro termo é utilizado largamente nos estudos acadêmicos, principalmente na psicologia e muitas vezes nas ciências sociais; o segundo, mais difundido no vocabulário jurídico (RIOS, 2009, p. 54).

No Brasil, poucos dados oficiais estão disponíveis sobre a violência homofóbica, em contrapartida, diariamente a mídia, por meio dos noticiários, estampa os numerosos crimes motivados por ódio e preconceito contra a comunidade LGBT como um todo. Em levantamento realizado pelo Grupo Gay da Bahia $(\mathrm{GGB})^{22} 445$ pessoas morreram no Brasil por motivos relacionados à homofobia, no ano de 2017, o que implica em um aumento em $30 \%$ em relação à 2016, trata-se do maior número de casos desde que o monitoramento passou a ser realizado anualmente pela entidade há 38 anos.

Este relatório traz à tona dados que devem subsidiar a elaboração de políticas públicas no combate e prevenção da violência homofóbica em todas as esferas autônomas da República. E não é só, a crescente onda de crimes de ódio contra a população LGBT fez renascer um intenso debate acerca da necessidade de sua criminalização específica a partir da inércia do Poder Legislativo em regulamentar o tema.

Dessume-se que os tipos penais genéricos já existentes, como a injúria, a lesão corporal e o homicídio, já abrangem a violência homofóbica, não se tratando, pois, da necessidade de criminalização de novas condutas ainda não elencadas no Código Penal, ou seja, de hipótese de novatio legis incriminadora, mas sim do mister de proceder-se a uma diferenciação qualitativa do tratamento sancionador destas condutas.

22 GGB. Relatório 2017 - Mortes violentas de LGBT no Brasil. Disponível em <https://homofobiamata.files.wordpress.com/2017/12/relatorio-2081.pdf>. 
Nesse contexto, a matéria foi levada até a apreciação do Supremo Tribunal Federal, por meio da Ação Direta de Inconstitucionalidade por Omissão (ADO) 26 e do Mandado de Injunção (MI) 4733. A ADO de autoria do Partido Popular Socialista visa a declaração da omissão do Congresso Nacional na tipificação específica de condutas relativas à homofobia e transfobia, em especial das ofensas individuais e coletivas, homicídios, agressões e discriminações motivadas pela orientação sexual da vítima. Como fundamentos, a ação pontua que o descumprimento da obrigação de legislar implica na violação da ordem constitucional prevista no artigo $5^{\circ}$ incisos XLII, XLI e LIV, que proíbe a proteção deficiente nos moldes do princípio da proporcionalidade.

Relativamente ao art. $5^{\circ}$, inc. XLI, da CF/88, peremptória é a lição de Luiz Carlos dos Santos Gonçalves, relator da comissão de juristas responsável pela elaboração do anteprojeto de novo Código Penal, acerca da omissão inconstitucional do legislador ao não criminalizar a homofobia:

A situação de maior gravidade, de omissão inconstitucional no sentido de
proteger penalmente vítimas de discriminações atentatórias aos direitos e
liberdades fundamentais, é a referente à orientação sexual. Embora a
ocorrência de crimes de ódio relacionados à opção sexual [sic] no Brasil
tenha crescido, a necessidade da legislação penal protetora ainda não foi
reconhecida pelo legislador. Homossexuais, bissexuais, transexuais têm
tolhido seu espaço de liberdade e escolha porque graves condutas de
intolerância ainda não receberam a diferenciada descrição típica penal que a
Constituição, no artigo $5^{\circ}$, XLI, exige. Trata-se de omissão inconstitucional.
O artigo $5^{\circ}$, inciso XLI, da Constituição, pende de completa regulamentação
(GONÇALVES, 2007, p. 285).

Neste desiderato, preconizam os autores da mencionada ação que a homofobia e a transfobia constituem espécies do gênero racismo, na medida em que racismo é toda ideologia que pregue a superioridade/inferioridade de um grupo relativamente a outro (e implicam necessariamente na inferiorização da população LGBT relativamente a pessoas heterossexuais cisgêneras - que se identificam com o próprio gênero), razão pela qual impõe-se ao legislador o dever de elaboração de legislação criminal que puna o racismo, donde também o racismo homofóbico e transfóbico ${ }^{23}$.

O Mandado de Injunção impetrado pela Associação Brasileira de Gays, Lésbicas e Transgêneros (ABGLT) objetiva, nos mesmos moldes da ADO, a criminalização das condutas ilícitas motivadas por preconceito relativo à orientação sexual. Ressalta-se que ambas as ações possuem a mesma finalidade e servem ao mesmo propósito, combater a omissão

\footnotetext{
${ }^{23}$ Ver petição inicial da ADO 26, proposta pelo PPS (Partido Popular Socialista).
} 
legislativa e garantir efetividade a normas constitucionais que precisam de regulamentação, e estão em pauta para julgamento conjunto no Plenário do Supremo Tribunal Federal.

Do total de onze ministros, quatro já votaram favoravelmente no sentido de que a homofobia deve ser criminalizada, considerando que o Congresso Nacional foi omisso e que deve aprovar uma lei específica para regulamentar crimes de discriminação por orientação sexual ou identidade de gênero, mas a definição do plenário será possível apenas após a finalização do julgamento:

A omissão do Estado - que deixa de cumprir, em maior ou em menor extensão, a imposição ditada pelo texto constitucional (como aquela que deriva do art. $5^{\text {a }}$, XLI e XLII, de nossa Lei Fundamental) - qualifica-se como comportamento revestido da maior gravidade político-jurídica, eis que, mediante inércia, o Poder Público também desrespeita a Constituição, também ofende direitos que nela se fundam e também impede, por ausência (ou insuficiência) de medidas concretizadoras, a própria aplicabilidade dos postulados da Lei Fundamental. Todas essas premissas que venho de expor autorizam-me a reconhecer a existência, na espécie, de situação de evidente e inconstitucional inércia estatal inteiramente imputável ao Congresso Nacional (BRASIL, online, 2019).

Dos votos já proferidos, conclui-se que além do reconhecimento da omissão legislativa e da ciência ao Congresso para suprir a omissão, a Suprema Corte adotou, até o presente momento, uma posição concretista direta, interpretando de forma ampliativa os dispositivos incriminadores da Lei 7.716/89 e também do Código Penal, para enquadrar a homofobia e a transfobia nos tipos penais definidos em seus dispositivos a partir da conclusão do julgamento e até que sobrevenha legislação autônoma do Congresso Nacional (STF, online, 2019).

Destaca-se que esta atuação expansiva da jurisdição constitucional é consectário do neoconstitucionalismo, também chamado de constitucionalismo moderno, que valoriza a força normativa da Constituição e que está intimamente associado a um novo paradigma ${ }^{24}$ de concrerização dos princípios e direitos fundamentais, possuindo como marco-filosófico o póspositivismo. Nessa perspectiva, o Poder Judiciário serviria como uma espécie de garantidor do cumprimento dos direitos fundamentais, podendo obrigar os demais poderes a cumprirem os comandos constitucionais.

\footnotetext{
${ }^{24}$ Segundo Barroso (2005, p.4): Uma das grandes mudanças de paradigma ocorridas ao longo do século XX foi a atribuição à norma constitucional do status de norma jurídica. Superou-se, assim, o modelo que vigorou na Europa até meados do século passado, no qual a Constituição era vista como um documento essencialmente político, um convite à atuação dos Poderes Públicos. A concretização de suas propostas ficava invariavelmente condicionada à liberdade de conformação do legislador ou à discricionariedade do administrador. Ao Judiciário não se reconhecia qualquer papel relevante na realização do conteúdo da Constituição.
} 
Do ponto de vista metodológico-formal, o constitucionalismo atual opera sobre três premissas fundamentais, das quais depende em boa parte a compreensão dos sistemas jurídicos ocidentais contemporâneos. São elas: (i) a normatividade da Constituição, isto é, o reconhecimento de que as disposições constitucionais são normas jurídicas, dotadas, como as demais, de imperatividade; (ii) a superioridade da Constituição sobre o restante da ordem jurídica (cuida-se aqui de Constituições rígidas, portanto); e (iii) a centralidade da Carta nos sistemas jurídicos, por força do fato de que os demais ramos do Direito devem ser compreendidos e interpretados a partir do que dispõe a Constituição (BARCELLOS, 2005, p. 2).

Com isso, apesar do Supremo Tribunal Federal tentar afastar veementemente este rótulo, é possível verificar a adoção de uma postura não só ativista do Judiciário, mas uma atuação semelhante a de legislador positivo, pois, ao classificar como crimes de preconceito e de injúria racial, respectivamente, as condutas resultantes de discriminação e que ofendem a honra subjetiva em face da orientação sexual, a Corte Constitucional instituiu um novo tipo penal, ampliando o rol taxativo previsto nas leis correspondentes.

Partindo-se para uma análise crítica e eminentemente jurídica desta atuação, verifica-se que o pedido inicial de aplicação analógica da Lei do Racismo para as discriminações referentes à orientação sexual fere, inicialmente, o princípio penal que veda a analogia in malam partem, uma vez que o rol do art. $20^{25}$ da referida lei possui um rol taxativo das elementares que constituem o crime e, a tipificação de uma conduta sem as formalidades exigidas viola o princípio da legalidade, considerado como cláusula pétrea e garantia fundamental, previsto no art. $1^{\circ}$ do Código Penal ${ }^{26}$ na sua forma de "lex stricta":

[...] no âmbito do Direito Penal incriminador, o que vale é o princípio da reserva legal, ou seja, só o Parlamento, exclusivamente, pode aprovar crimes e penas. Dentre as garantias que emanam do princípio da legalidade, achamse a reserva legal (só o Parlamento pode legislar sobre o Direito Penal incriminador) e a anterioridade ('lex populi' e 'lex praevia', respectivamente). Lei não aprovada pelo Parlamento não é válida (GOMES e MAZZUOLI, 2009, p. 349).

Com fundamento neste princípio, o STF decidiu anteriormente pela atipicidade da discriminação em face da orientação sexual justamente por não haver correspondente legislativo que justificasse a tipificação formal da conduta como criminosa: "Proferir manifestação de natureza discriminatória em relação aos homossexuais não configura o crime do art. 20 da Lei n ${ }^{\circ}$ 7.716/86, sendo conduta atípica” (BRASIL, online, 2014 - Info 754).

\footnotetext{
${ }^{25}$ Art. 20 da Lei 7.716/1989 - "Praticar, induzir ou incitar a discriminação ou preconceito de raça, cor, etnia, religião ou procedência nacional".

${ }^{26}$ Art. $1^{\circ}$ do Código Penal - Não há crime sem lei anterior que o defina. Não há pena sem prévia cominação legal.
} 
Naquela oportunidade, o Ministro Barroso, assim como os demais que proferiram seus votos contrários ao enquadramento típico da conduta, manifestou no plano moral a sua completa indignação quanto ao desvalor de qualquer ato que importe em discriminação, notadamente a de cunho sexual, porém, tal reprovabilidade não seria suficiente para punir alguém sem que uma lei anterior que defina a conduta como crime:

De modo que, no plano das ideias, eu diria que o desvalor da proposição aqui em discussão ultrapassa todos os limites do erro, mas, a meu ver, não ingressa na esfera do crime. Até porque, como Vossa Excelência observou, Ministro Marco Aurélio, a tipificação do art. 20 da lei $n^{\circ} 7.716$, desde a sua ementa, define os crimes resultantes de preconceito de raça ou de cor e, em seguida, o art. 20, numa tipificação estrita como próprio, também se refere a raça, cor, etnia, religião ou procedência nacional. [...] De modo que eu acho que vulneraria princípios que nós consideramos importantes se a própria jurisprudência do Supremo Tribunal Federal punisse criminalmente alguém sem que uma lei claramente defina essa conduta como ilícita. De modo que, por mais reprovável que se considere essa manifestação no plano moral, eu penso que não é possível tipificá-la penalmente, de modo que estou acompanhando Vossa Excelência pelo não recebimento da denúncia (BRASIL, online, 2014).

Apesar da mudança de entendimento, verifica-se que os fundamentos jurídicos que embasaram a decisão anterior continuam plenamente válidos e atuais e a criminalização da conduta pela via judicial transversa, por mais abjeta que esta seja, pode suscitar uma série de problemas relacionados à legalidade e formalidade das normas, como a necessidade de manutenção da segurança do ordenamento jurídico, a violação ao princípio basilar democrático da separação dos poderes ${ }^{27}$ e a ideia de reserva legislativa para a inserção de tipos penais incriminadores.

Ao analisar a possibilidade jurídico-constitucional de o Supremo Tribunal Federal, mediante provimento jurisdicional, tipificar delitos e cominar sanções penais, superando-se o princípio segundo o qual “nullum crimen, nulla poena sine praevia lege”, o próprio relator da ADO 26, Ministro Celso de Mello, afirmou em seu voto não ser possível a usurpação da competência do Legislativo para tal finalidade:

Entendo que não. É que a pretensão em referência - por importar em inadmissível substituição do Congresso Nacional - veicula clara transgressão ao postulado constitucional da separação de poderes e, também,

\footnotetext{
${ }^{27}$ Montesquieu, no livro "O Espírito das Leis" analisa que a separação dos poderes impede o arbítrio e está relacionada com o garantir democrático: [...] não haverá liberdade se o poder de julgar não estiver separado do poder legislativo e do executivo. Se estivesse ligado ao poder legislativo, o poder sobre a vida e a liberdade dos cidadãos seria arbitrário, pois o juiz seria legislador. Se estivesse ao poder executivo, o juiz poderia ter a força de um opressor. Tudo estaria perdido se o mesmo homem ou o mesmo corpo dos príncipes ou dos nobres, ou do povo exercesse esses três poderes. O de fazer as leis, o de executar as resoluções públicas e o de julgar os crimes ou as divergências dos indivíduos. (MONTESQUIEU, 1996, p. 187).
} 
ofensa manifesta ao princípio da reserva absoluta de lei formal em matéria de índole penal. Como se sabe, a definição típica das condutas delituosas está subordinada ao postulado constitucional da reserva absoluta de lei formal (CF, art. 5o, XXXIX), o que inviabiliza qualquer pleito cujo acolhimento implique desconsideração dessa garantia fundamental, segundo a qual não há crime nem pena sem lei anterior que os defina, excluída, portanto, a possibilidade de utilização de provimento jurisdicional como sucedâneo de norma legal (BRASIL, online, 2014).

Em contraposição à esta crítica, argumenta o Ministro Celso de Mello em seu voto que não se trata de aplicação analógica prejudicial de norma penal e não se cuida, também, de formulação de tipos criminais, nem de cominação de sanções penais, pois é inviável juridicamente a criminalização de condutas mediante provimentos jurisdicionais, mas sim de "mera subsunção de condutas homotransfóbicas aos diversos preceitos primários de incriminação definidos em legislação penal já existente (a Lei n ${ }^{\circ} 7.716 / 89$, no caso), na medida em que atos de homofobia e de transfobia constituem concretas manifestações de racismo, compreendido este em sua dimensão social: o denominado racismo social" (BRASIL, online, 2014).

Outro ponto que enseja críticas à criminalização da homofobia pelo Judiciário diz respeito à impossibilidade de o Judiciário obrigar o Legislativo a adotar outra postura no que tange à política criminal. De acordo com o conceito adotado por Zaffaroni e Pierangeli (2015, p. 132) é possível definir a política criminal como a ciência ou a arte de selecionar os bens jurídicos que merecem a tutela penal do Estado, ou seja, a política criminal é um mecanismo discursivo, social e político para identificar quais condutas merecem ser criminalizadas, bem como para determinar as estratégias de aplicação do poder punitivo (FERREIRA, 2017, p. 29).

Nesse sentido, o Judiciário somente poderia compelir o Legislativo a fornecer proteção jurídico-penal a determinadas condutas nos casos de desobediência aos mandados expressos de criminalização, como nos casos de crimes hediondos, racismo e terrorismo. Noutro giro, não significa que os mandados implícitos de criminalização não possam servir de fundamento para a criação de leis, mas não haveria uma obrigatoriedade do legislador nestes casos, uma vez que a sua ordem não é clara:

Condição mais controversa, todavia, se guarda aos assim chamados mandados constitucionais de criminalização implícitos. Muito natural: em uma doutrina habituada à figura do Direito Penal como ultima ratio legis e como manifestação da limitação à atuação do direito de punir do Estado, é bastante difícil admitir que o texto constitucional imponha o dever de criar crimes de modo não claro ou não explícito (DISSENHA, 2008, p. 333). 
Nessa linha de intelecção, não significa dizer que a criminalização da homofobia não seja legítima, mas que não seria obrigatória, "na medida em que a tipificação de uma conduta normalmente envolveria um juízo de ampla discricionariedade legislativa para identificar o direito penal como a via mais adequada para a proteção do valor ou bem juridicamente tutelado" (FERNANDES, 2014, p. 63).

Assim, não restam dúvidas de que a criminalização da homofobia é legítima, porém, ainda que a criminalização de determinada conduta esteja de acordo com os ditames constitucionais, o caráter fragmentário do direito penal exige a punição somente dos bens elevados ao patamar de maior relevância dentro do ordenamento jurídico, no sentido de necessitarem de proteção penal, portanto, a Constituição traçaria somente os limites da atividade legislativo-criminalizadora, cabendo ao Legislativo eleger tais bens com base em estudos de política criminal, e ao Judiciário realizar o controle da constitucionalidade da criminalização (FERNANDES, 2014, p. 63).

De qualquer forma, conforme a previsão Constitucional da divisão de poderes (art. 2. ${ }^{\circ}$ da $\mathrm{CF}$ ), foi conferido ao legislador a competência para a qualificação dos bens passíveis de tutela estatal, bem como para a definição dos limites de sua proteção, sendo que os freios e contrapesos existem exatamente para que o arranjo democrático não seja violado pela prevalência de um poder sobre o outro. Assim, a função do Judiciário “está em promover o controle da constitucionalidade, enquanto guardião da jurisdição constitucional e jamais em substituir o governo e o legislador" (MACHADO, 2011, p. 142).

É possível aviltar, desse modo, que o legislador ordinário tenha feito a opção de não criminalizar a homofobia não por ser um bem jurídico que não merece proteção, mas por razões exclusivas de política criminal que levem à concluir que a tipificação penal, por si só, não seria eficaz para a solução do problema, ou, ainda, por entender que já existe proteção penal, ainda que carente de especificidade, mas que abarca os bens jurídicos em questão, ou, também, em face da inflação legislativa do direito penal que em muitos casos cumpre apenas uma função simbólica de agradar a sociedade e atender à pressão popular ou midiática.

É o legislador o indivíduo capaz de aplicar essa política criminal sob um viés humanitário. É ele, e não o texto constitucional que, justamente por garantia do cidadão, é rígido o suficiente para impedir modificações às pressas, que é capaz de entender a historicidade do direito e da sociedade. É o legislador que tem a possibilidade de compreender o que muda no seio social, quais os novos anseios e quais os antigos. $\mathrm{O}$ que demanda proteção, o que não pede por ela e, finalmente, aquilo que requer a mais violenta proteção do Direito: a tutela penal (DISSENHA, 2008, p. 342). 
Nessa ordem de ideias, poderia argumentar-se que a utilização do princípio da dignidade e da vedação da proteção insuficiente, além do mandado de criminalização genérico previsto no art. $5^{\circ}$, LXI da Constituição, como consectários para a criação de novos crimes poderia abrir um leque indeterminado de possibilidades e de condutas a serem criminalizadas pelo Supremo Tribunal Federal, pois a violação aos direitos LGBT é apenas uma das pautas em discussão que versam sobre a carência legislativa.

Apesar das críticas, é certo que, sem a decisão do Supremo, não se pode afirmar que seria possível conseguir a imprescindível mobilização social para que a discussão deixasse de ser pano de fundo e assumisse protagonismo nas esferas políticas. Entretanto, o debate do tema, por si só, a despeito de configurar relevante avanço, não é suficiente para alterar a realidade. $\mathrm{O}$ assunto demanda efetivo preparo da sociedade, destacadamente no que diz respeito à educação que, sem dúvida, é o melhor caminho para a obtenção de informação e a desmistificação dos preconceitos.

De toda forma, a saída encontrada pelo Judiciário para sanar a omissão legislativa e garantir a proteção dos direitos é provisória, pois não pode haver supremacia judicial em relação aos demais poderes, no sentido material, razão pela qual a ideia de diálogos institucionais e de cooperação podem ser a melhor saída para a solução de conflitos entre os poderes, que, trabalhando juntos e incitando na sociedade o debate salutar sobre o tema, podem chegar a melhor saída para a redução do grave problema relacionado ao desrespeito dos direitos LGBT.

\section{Considerações finais}

As violências sofridas por homossexuais no Brasil são frequentes e estão em constante crescimento, legitimando a prática contínua de atos de preconceito e discriminação. Isso demonstra a inefetividade do Estado em assegurar a proteção dos direitos dos grupos LGBT, considerados minoria no cenário político brasileiro, e a urgente necessidade de adoção de uma postura mais ativa dos Poderes Públicos para evitar que condutas como estas continuem sendo pauta reiterada nos noticiários brasileiros.

Apesar da evolução no campo jurídico da proteção dos direitos LGBT, especialmente na esfera civil, verifica-se que a normativização no âmbito penal carece de especificidade, sendo que os atos ilícitos que violam a dignidade e orientação sexual acabam sendo classificados nos tipos penais genéricos existentes, que são insuficientes para tutelar a 
gama de violações que usualmente se verifica, notadamente no que concerne ao preconceito e à discriminação destas minorias.

Nesse ponto, a criminalização da homofobia é legítima como tentativa do Estado em mudar essa realidade, tutelando estes bens jurídicos no campo da ultima ratio do direito, no sentido de que somente se deve recorrer ao direito penal quando nenhum outro ramo do direito foi capaz de solucionar o problema, conforme preconizam o princípio da fragmentariedade e da intervenção mínima.

Desta feita, extrai-se que a necessidade da criminalização desta conduta é demanda social das mais relevantes, sendo que o Legislativo, em sua competência de elaborador de normas penais, não tem atuado de forma suficiente e com a urgência necessária para tratar do assunto, quedando-se inerte frente a violação dos direitos fundamentais em discussão.

O Judiciário, que vem adotando postura ativista nas últimas décadas, sobretudo após a promulgação da Constituição Federal de 1988 que ampliou o rol de direitos fundamentalmente assegurados, instado a decidir sobre o assunto e tomar uma decisão frente ao silêncio legislativo, optou por reconhecer, até a conclusão deste trabalho, o estado de mora inconstitucional do Congresso Nacional na proteção integral dos direitos da comunidade LGBT e de criminalizar provisoriamente a homofobia até que sobrevenha norma específica editada pelo Legislativo.

Em análise crítica, o presente trabalho buscou abordar as questões jurídicas que questionam a atitude do Supremo no sentido de que esta atuação como legislador positivo infringiria preceitos penais, como a vedação de analogia in mallam partem e da legalidade, e até mesmo constitucionais, como a separação de poderes e a ilegitimidade democrática para legislar.

O Supremo Tribunal Federal rebate todos estes os argumentos nos votos apresentados até o presente momento no julgamento da ADO 26 e MI 4733, justificando que a sua atuação não tipifica condutas, mas apenas confere uma interpretação do conceito de raça trazido pela Lei $n^{\circ}$ 7.716/89 conforme à Constituição, apoiando-se nos princípios da liberdade e da igualdade, bem como na cláusula impeditiva constitucional que veda qualquer forma de tratamento discriminatório.

Todavia, é possível concluir que talvez o caminho da criminalização imediata por meio da decisão concretista não seja o mais correto, pois, a forma como foi colocada nos votos, a despeito de uma cognição exauriente, a criminalização da homofobia pelo Poder Legislativo se tornaria obsoleta e desnecessária a partir da conclusão do julgamento, já que 
independentemente da sua articulação para elaboração de norma específica sobre o assunto, a Corte Constitucional já determinou a sua pronta aplicabilidade.

À luz das digressões tecidas, denota-se que, em que pese a polêmica postura adotada pelo Judiciário neste julgamento, que configurou uma manobra interpretativa, é inegável que a discussão trouxe à tona o interesse da sociedade em debater o assunto e tentar encontrar uma saída para a redução das violações perpetradas contra os direitos da comunidade LGBT, destacando-se que a criminalização da conduta não é garantia eficaz de proteção do bem jurídico e que as atitudes estatais precisam transcender o simbolismo da tipificação penal para se concretizarem em políticas públicas que produzam efeitos práticos na garantia das liberdades fundamentais.

\section{Referências}

BARCELOS, Ana Paula de. Neoconstitucionalismo, Direitos fundamentais e controle das políticas públicas. Revista de Direito Administrativo, Rio de Janeiro, v. 240, p. 83-105, abr. 2005. Disponível em: <http://bibliotecadigital.fgv.br/ojs/index.php/rda/article/view/43620>. Acesso em: 20 Fev. 2020.

BARROSO, Luís Roberto. Judicialização, ativismo judicial e legitimidade democrática. Revista EMARF, Cadernos Temáticos: Seminário Nacional sobre Justiça Constitucional, dez. 2010.

BARROSO, Luís Roberto. Neoconstitucionalismo e constitucionalização do Direito (O triunfo tardio do direito constitucional no Brasil). 2005. Disponível em:

$<\mathrm{http}$ ://www.luisrobertobarroso.com.br/wpcontent/themes/LRB/pdf/neoconstitucionalismo_e_constitucionalizacao_do_direito_pt.pdf> Acesso em 20 fev. 2020.

BITENCOURT, Cezar Roberto. Tratado de direito penal, v. 2, 17ª edição., 17th edição. Editora Saraiva, 2017.

BORRILLO, Daniel. Homofobia. História e crítica de um preconceito, Tradução de Guilherme João de Freitas Teixeira, 1a Edição, Belo Horizonte: Editora Autêntica, 2000, p. 106. G.n.

BRASIL, Supremo Tribunal Federal. Ação Direta de Inconstitucionalidade 1351/DF. Plenário. Rel. Min. Marco Aurélio. Brasília, DJe 07/06/2006.

BRASIL, Supremo Tribunal Federal. Ação Direta de Inconstitucionalidade por Omissão 26/DF. Rel. Min. Celso de Mello. Brasília, DJe 20/02/2019.

BRASIL. Supremo Tribunal Federal. Inquérito 3590/DF. Primeira Turma. Rel. Min. Marco Aurélio. Brasília, DJe 12/8/2014 - Info 754. 
BRASIL. Supremo Tribunal Federal. Medida cautelar na Arguição de Descumprimento de Preceito Fundamental 347. Relator: Ministro Marco Aurélio. Brasília, 9 de setembro de 2015. Disponível em $<$ http://redir.stf.jus.br/paginadorpub/paginador.jsp?docTP=TP\&docID=10300665>. Acesso em 17 set. 2017.

BREGA FILHO, V.; ALVES, F.B. Termidorizar a Deliberação: O Papel das Cortes Constitucionais nas Democracias Contemporâneas. Revista Brasileira de Direito, v. 11, p. 124-134, 2015. Disponível em: https://dialnet.unirioja.es/descarga/articulo/5179375.pdf

CAMPOS, Carlos Alexandre de Azevedo. Dimensões do ativismo judicial do STF. Rio de Janeiro: Forense, 2014.

DISSENHA, Rui Carlo. Mandados constitucionais de criminalização: uma análise da questão sob a ótica do Direito Penal nacional. Raízes Jurídicas. Curitiba, v. 4, n. 2, jul./dez. 2008.

DWORKIN, Ronald. O império do direito. São Paulo: Martins Fontes, 1999.

FELDENS, Dinamara Garcia; MOTA, Marlton Fontes; e MELO, Lilian Jordeline Ferreira de. A legitimidade da população LBGT aos direitos sexuais para uma cidadania plena. Interfaces Científicas - Humanas e Sociais • Aracaju • V.6 • N.2 • p. 77 - 86 • Out. 2017. FERNANDES, Eric Baracho Dore. Omissões inconstitucionais e mandados constitucionais de criminalização: o Mandado de Injunção no 4733 e a criminalização da homofobia. Observatório da Jurisdição Constitucional. Brasília: IDP, Ano 7, no. 2, jul/dez. 2014.

FERREIRA, Carolina Costa. A política criminal no processo legislativo. Belo Horizonte: Editora D'Plácido, 2017.

GOMES, Luiz Flávio; MAZZUOLI, Valerio de Oliveira. Comentários à Convenção Americana sobre Direitos Humanos: Pacto de San José da Costa Rica. 2. ed. rev., atual. e ampl. São Paulo: Revista dos Tribunais, 2009.

GONÇALVES, Luiz Carlos dos Santos. Mandados Expressos de Criminalização e a Proteção de Direitos Fundamentais na Constituição Brasileira de 1988, $1^{a}$ Edição, Belo Horizonte: Editora Forum, 2007, p. 285. G.n.

GORISCH, Patrícia. O reconhecimento dos direitos humanos LGBT: de Stenowall à ONU. Curitiba: Appris, 2014.

ILGA -International Lesbian, Gay, Bisexual, Trans and Intersex Association. Edição do relatório ILGA's State-Sponsored Homophobia by Lucas Ramón Mendos de 20 de março de 2019. Disponível em: 〈https://ilga.org/maps-sexual-orientation-laws〉. Acesso em: 06 mar. 2019.

LOPES, Ana Maria D'avila. Proteção constitucional dos direitos fundamentais culturais das minorias sob a perspectiva do multiculturalismo. Revista de Informação Legislativa, Brasilia, v.45, n.177, p.19-29, jan./mar.2008. 
MACHADO, Edinilson Donisete. Ativismo judicial: limites democráticos e constitucionais. 1 ed. São Paulo: Letras Jurídicas, 2011.

MIARELLI, Mayra Marinho; LIMA. Rogério Montai de. Ativismo Judicial e a efetivação de direitos no Supremo Tribunal Federal. Porto Alegre: Sergio Antonio Fabris, 2012.

MIRANDA, Jorge. Direitos Fundamentais: uma perspectiva de futuro. Atlas, 2013. VitalBook file. Minha Biblioteca. Disponível em: <http://online.minhabiblioteca.com.br/books/9788522481095>. Acesso em: 21 mar. 2019. MONTESQUIEU, Charles de Secondat. O Espírito das Leis. $2^{\circ}$ ed. São Paulo: Martins Fontes, 1996.

MORAES, Alexandre de. Direito Constitucional, $28^{a}$ ed. São Paulo: Atlas, 2012.

NUCCI, Guilherme de Souza. Leis Penais e Processuais Penais Comentadas, $5^{\text {a }}$ Edição, São Paulo: Editora Revista dos Tribunais, 2010, pp. 300-306. G.n.

PEREIRA, Luciano Meneguetti e SALVIANO, Mauricio de Carvalho. In L. M. Pereira (Org.). O Brasil e o direito internacional: conflitos e convergências. 1. ed. -- Birigui, São Paulo: Boreal Editora, 2015.

PRADO, Marco Aurélio Máximo e JUNQUEIRA, Rogério Diniz. Homofobia, hierarquização e humilhação social. In: VENTURI, Gustavo e BOKANY, Vilma. Diversidade Sexual e Homofobia no Brasil, $1^{\text {a }}$ Ed., São Paulo: Ed. Perseu Abramo, 2011, pp. 57 e 60.

RIOS, Roger Raupp. O conceito de homofobia na perspectiva dos direitos humanos e no contexto dos estudos sobre preconceito e discriminação, in RIOS, Roger Raupp (org.). Em defesa dos DIREITOS SEXUAIS, $1^{\text {a }}$ Edição, Porto Alegre: Editora Livraria do Advogado, 2006, pp. 113, 114, 118, 119, 120, 122, 128-129 e 131-134.

SARMENTO, Daniel. Ubiquidade constitucional: os dois lados da moeda. In NETO, Cláudio Pereira de Souza; SARMENTO, Daniel (Org.). A constitucionalização do direito: fundamentos teóricos e aplicações específicas. Rio de Janeiro. 2007. Lúmen Júris.

TEIXEIRA, Anderson Vichinkeski. Ativismo judicial: nos limites entre racionalidade jurídica e decisão política. Rev. Direito GV. v.8 n 1 São Paulo, 2012.

ZAFFARONI, Eugenio Raúl; PIERANGELI, José Henrique. Manual de direito penal brasileiro: parte geral. 11. ed. São Paulo: Revista dos Tribunais, 2015. 
Data de recebimento: 03.06 .2020

Data de aprovação: 08.08.2020 